\title{
Training and Competence Development in the SME Sector: The Hungarian Case ${ }^{*}$
}

\author{
Csaba Makó
}

The lack of systematic knowledge on the SMEs training practices could be explained by the lack of financial resources and the low-motivation of managers to invest in skill development. This is the so-called "competence paradox”, according to which firms investing in their employees' competence development simultaneously increase the risk that these employees will leave the company. Contrary to the traditional quantitative, survey based approach on SMEs training practices, this analysis intends to better understand such kind of non formalised practice of learning in the company practice, using the empirical experiences of case studies in three selected sector. One of the most important methodological messages of this research project is that the ,right mix" of both quantitative and qualitative research techniques is able to describe the variety of competence development and training in the SMEs.

Das Fehlen systematischer Kenntnisse bei SME Trainingspraktiken kann durch fehlende finanzielle Ressourcen und die fehlende Motivation von Managern, in die Qualifikationsentwicklung zu investieren, erklärt werden. Dies ist das sog. „,Kompetenzparadox", danach erhöht die Kompetenzentwicklung gleichzeitig das Risiko, dass die Angestellten die Firma verlassen werden. Konträr zur traditionell quantitativen umfragebasierten Methode der SME Praktiken versucht diese Analyse die Praxis informellen Lernens besser zu verstehen, anhand empirischer Erfahrungen von Fallstudien in drei ausgesuchten Sektoren. Eine der wichtigsten Erfahrungen aus dem Projekt ist, dass der "richtige Mix“ von quantitativen und qualitativen Forschungstechniken die Vielfalt in der Kompetenzentwicklung und dem Training in den SMEs hineichend erklären kann.

Key words: SMEs / Hungary / training practices / competence / case studies /

\footnotetext{
Manuscript received: 05.04.05, accepted: 11.04 .05 (no revision)

** Csaba Makó, Research Director at the Institute of Sociology Hungarian Academy of Sciences, Budapest. Main research areas: Organisational-institutional innovations and learning process, labour relations in international perspective and the emerging new patterns of work organisation and management related to the use of ICT. Corresponding address: Mako@socio.mta.hu
} 


\section{Introduction: Theoretical and Methodological Background ${ }^{1}$}

Evaluating training practice in general and especially in the SME sector, no social actor can be found who is questioning the importance to develop human resources - including skill and knowledge improvement during the life-long learning - meaning to increase competitiveness of the European economy (Lisbon Summit guidelines, 2000). This consensus among the social actors is based on the new growth theories. The latter make the economic development or wealth accrual more dependent on the intensity of accumulation of human capital (defined by the combination of levels of knowledge, skills and competencies of workforce) than on the rate of accumulation of physical capital.

Beside this general consent among social actors on the increasing role of human capital in the economic and social development, a lot of both theoretical as well as methodological problems make it difficult to understand and assess the role of knowledge in the performance of the business organisation in general and in the SME sector in particular. We have to confront further difficulties, when we try to compare and evaluate the situation of SMEs in the EU-15 countries and the New Member Countries (NMC). (See the SME definition in the table 1 in Appendix.) The recent phase of enlargement of the EU, which includes countries from Central and Eastern Europe and from the Mediterranean, took place in May 2004. The enlargement certainly will open a new challenging area for the social and economic actors in the „old" and „new” member countries. In the EU-25, a variety of legal, social and cultural norms both in human resource utilisation as well as working conditions in a large sense across Europe creates unprecedented pressure for the policy makers to better understand the new realities. Among many challenges, one of the most important one is how to create a more competitive/flexible and at the same time socially stable/cohesive New Europe. To avoid illusions and elaborate comprehensive and workable policies in the field of knowledge and competence development, it is necessary to understand the heterogeneity of practices in EU-25 countries.

Unfortunately, there are rather few comparative studies aimed at comparing the various dimension of human resources utilisation in the economy, (and) especially in relation with the SME sector. Listing the various EU level research initiatives, comparative projects focused on the working and life conditions, including training and knowledge use were launched at the very end of the 1990s and published at the beginning of this millennium. The following table

1 The results of the paper are based on the empirical researches supported by the following EU Projects: "Community Vocational Training Action Program" (Leonardo Project 2003-3448/001-LE2-510REF) and "Representation and Voice in Small and Medium-sized European Enterprises: Monitoring Actors, Labour Organisations and Legal Frameworks" (SMALL) (SERD-2002-00184). 
summarises the data resources utilised in the report on training and knowledge use in the business organisation, including SMEs.

Table 1. Main Data Sources Used in this Report on the Firms' Training Practice

\begin{tabular}{|c|c|c|c|}
\hline Data source & Data base & $\begin{array}{l}\text { Period } \\
\text { covered }\end{array}$ & Further information \\
\hline $\begin{array}{l}\text { European Foundation } \\
\text { for Improvement of } \\
\text { Living and Working } \\
\text { Conditions }\end{array}$ & Working conditions & 2001 & www.eurofound.eu.int \\
\hline $\begin{array}{l}\text { Eurostat or „SMEs in } \\
\text { Europe” } \\
\text { (Competitiveness, } \\
\text { innovation and the } \\
\text { knowledge-driven } \\
\text { society) }\end{array}$ & $\begin{array}{l}\text { Continuing Vocational } \\
\text { Training Survey } \\
\text { (CVTS) }\end{array}$ & $1996-2001$ & $\begin{array}{l}\text { www.europa.eu.int/comm } \\
\text { /eurostat }\end{array}$ \\
\hline DG-IST & Tele-work (e-GAP) & $2002-2004$ & www.egap-eu.com \\
\hline SMALL project & $\begin{array}{l}\text { Case Study in the } \\
\text { following sectors: ICT, } \\
\text { clothing, tourism and } \\
\text { health care }\end{array}$ & $2003-2004$ & \\
\hline $\begin{array}{l}\text { Innopark and National } \\
\text { Employment Fund }\end{array}$ & $\begin{array}{l}\text { Competitiveness and } \\
\text { Employment } \\
\text { Generation } \\
\text { (Dunaújváros mini- } \\
\text { region }\end{array}$ & $2002-2003$ & www.socio.mta.hu/sow \\
\hline
\end{tabular}

None of the comparative statistical analysis or comparative data collections includes all EU-15 and NMC. However, in relation with the SMALL project countries, Bulgaria and Hungary were both analysed in the Eurostat organised Continuous Vocational Training Survey (CVTS 1999) as well as in the European Working and Life Conditions Survey (2001). In the international telework survey (e-GAP) only a Hungarian region did participate in the international comparison.

Before presenting the general picture of the vocational training in Hungarian firms and in the SMEs sector, the notions and definitions closely related to the training practice are worth to be briefly presented. The key reason for this exercise is to improve theoretical and methodological foundations of knowledge creation, development and use in the practice of business organisation in general and in the SME sector in particular. Another important practical argument is that until today, the overwhelming majority of studies dealing with the firm-level training practices were mainly focusingon formal training activities that are easy to understand and measure by (such) formal indicators as time and financial resources spent on training. This supply of the latter is provided by educational and training institutions and usually legitimated by various forms of certificates. 
Finally, it is necessary to mention that the empirical studies conducted in the SMEs sector have failed to demonstrate a positive relationship between the firms' participation in formal training activities and economic performance and competitiveness of the firm.

To diminish the risks of interpretations and evaluation of formal training practices in SMEs, it is necessary to call attention to the particular importance „on-the-job training” (OJT) (,learning from others” or „learning by doing and using"). In this respect we share the following view concerning learning practice in the small enterprises: ", most of the learning is based on 'learning by doing'. Such training practices do result to recognise by standard measures (i.e. education level or diplomas). Traditional literature on SMEs training practices has very often ignored these non-formal methods such as learning by doing, visits to other enterprises, dialogue with customers and suppliers, personal development meetings, work rotation, staff meetings, etc. which are very important for SMEs" (Ylinenpaa 1997).

identifing and evaluating the importance of the non-formal elements of knowledge creation and development, there is a growing interest to use the notion of competence, which ", can be defined as the synthesis of knowledge (what you can learn in education), skills (what you gather in your job, at your workplace and in social life from your daily experiences) and aptitude (these are abilities to use this knowledge and skills)" (Argyris 1993). The EU Commission definition of competence basically covers the above listed contents or some of them considering it as the capacity to use qualification, experience and knowledge efficiently. In our analysis we adopt Nordhaug's so-called "Competence Chain Model" in focusing on the activities of SMEs aimed at upgrading their pool of competence in the following main fields ${ }^{2}$ :

a) „Development of in-house competence”, which represents the measures a firm takes to develop their competence base available within their inhouse human resources,

b) „External competence acquisition”, where firms acquire (buy or by other tools get access to) different external competencies that are outside the firms' boundaries and which are missing internally but may be evaluated as essential to keep competitiveness or simply survival of the firm (Makó, /Nemes 2003).

Unfortunately, there are rather few comparable data on the knowledge use and training practice of SMEs between the EU-15 and the New Member Countries (NMC) (plus Accession Candidate Countries (ACC) like Bulgaria, Romania and Turkey). For example the latest European review on the Continuous Vocational Training Survey (CVTS) covered just the period of 1996 to 2001 and only the

2 Competence Development in SMEs (2003). 
following NMC and ACC were involved in the project: Bulgaria, the Czech Republic, Estonia, Hungary, Lithuania, Latvia, Poland, Romania and Slovenia. Slovakia, Malta, and Cyprus were missing. No new CVTS has been organised (ever since). The other comprehensive survey on working conditions which covered both NMC and ACC surveyed 12000 workers and was carried out between 2001 and 2002. (The results of this working conditions survey were compared to the EU-15 country working conditions carried out in 2000 on the sample of 21500 workers.) However, no independent section was dealing with training, this issue was analysed only within the section of „work organization”.

\section{National Institutional Framework: Legal and Labour Relations System Regulation}

The practice of company training - including the SMEs - is not regulated directly by special law. Therefore, laws regulating Hungarian vocational training or adult education are representing the legal framework for the company training practice, too. Recently, these legal rules have been summarised into the law dealing with the adult education (Makó/Nemes 2003) However, the old legal regulations (e.g. Employment Act which is dealing with the training and retraining of unemployed or persons having a risk to be unemployed) are still valid. According to the law on the „vocational training contribution”, firms are obliged to pay 1.6 per cent of their wage fund for the central training fund or they use this amount of money themselves. Since 1996, various government decrees have determined how much per cent of the company's contribution could be used for the training of the firm's employees. This obligation to pay vocational training contribution should be performed in various forms (e.g. supporting vocational training school on contractual basis participating in the shop-floor training of young apprentices etc.). In 1993, the vocational training law indicated the importance of the National List of Occupations (in Hungarian: Országos Képzési Jegyzék, OKJ), which is playing an important normative role. For example, the firm intending to use its financial contribution for in house vocational training of their employeeshas a viable option only in the case of professions included in the list of OKJ.

Beside the briefly presented legal rules on vocational training, we have to note that the training of white collar employees is also regulated by the Employment Act (1991), while the Labour Code (1992) is regulating the conditions of the vocational training contracts. These are rather old legal rules, but still valid. Summing up, (we may say that) in the last one and a half decades various types of changes in the legal rules of the vocational training could be found and it is rather difficult to get a clear picture. According to educational experts, the following laws are representing the legal framework for vocational training:

1). 2001. CI Law on the ,adult education”, its realisation is jointly coordinated by the Ministry of Employment Policy and Labour and by the Ministry of 
Education. The questions, not regulated by this law, are ruled by the Law on vocational training (1993. LXXXVI. Law).

2). 2001. LI. Law on the „,vocational training contribution and on the support of developing educational system". ${ }^{3}$

Beside legal regulation, collective agreements as one basic institutional element of the labour relations system represent another important form of social regulation at the firm level. Training and re-training of employees in the micro and small firm's practice are not regulated by the collective bargaining and collective agreements, not even in the case of the middlesized firms. Only every tenth of firms have collective agreement. (See in detail table 2.)

Table 2. Collective Agreements (CA) by Size of the Firms (1998)

\begin{tabular}{|l|l|}
\hline $\begin{array}{l}\text { Size category of firms (number of } \\
\text { employees) }\end{array}$ & Share \\
\hline $5-20$ persons & $0.1 \%$ \\
\hline $21-49$ persons & $1.1 \%$ \\
\hline $50-49$ persons & $11.7 \%$ \\
\hline $300-499$ persons & $46.4 \%$ \\
\hline $500-999$ persons & $67.3 \%$ \\
\hline 1000 persons + & $75.4 \%$ \\
\hline
\end{tabular}

Source: Neumann (2002).

The low share of collective agreements in the SME sector should be attributed to the weak presence of trade union activity in this sector. Even in the case of the Works Council - which is an institutional tool of employees participation in the Hungarian firms - employers are obliged by law to establish this institution only in the firm having 50 employees at least, but there are no serious legal consequences of non-application of the law. Therefore, in the great majority of firms belonging to the category of micro and small firms employees have only individualised employment contracts with the employers, in which training obligations of employers are generally missing.

\section{Training Activity in the Firm: National and International Perspective}

Before giving an overview of the firm's level training activities, it is necessary to present a general picture of the relation of general educational level of employees and the size of business organisation. In developing entrepreneurial activity, the general education does not guarantee the necessary knowledge base. Therefore it is necessary to combine the general knowledge with professional

3 This law was accepted on 19th of June 2001 and published on 5th July 2001 (CD - Jogász (B) 2.20). 
skills acquired through vocational training. In the sectors in which the share of micro firm owners is high, not only the certificate of general education but also diploma of vocational training is highly necessary. In addition, in the micro firms $(0-9$ persons $)$ the share of employees with only primary school education is smaller than the average. On the contrary, more people with university or college degree worked there. The share of persons with university degree is similar in all size categories of firms in the competitive sector in Hungary.

Table 3. Education/Qualification of Employees and the Size of the Company, 2002

\begin{tabular}{|l|r|r|r|r|r|}
\hline \multirow{2}{*}{} & \multicolumn{5}{|c|}{$\begin{array}{c}\text { The distribution of employees with respect to } \\
\text { education/qualification and company size }\end{array}$} \\
\cline { 2 - 6 } & \multicolumn{5}{|c|}{ Size of company } \\
\hline Highest education/qualification level & $\begin{array}{c}\mathbf{0 - 9} \\
\text { persons }\end{array}$ & $\begin{array}{c}\mathbf{1 0 - 4 9} \\
\text { persons }\end{array}$ & $\begin{array}{c}\mathbf{5 0 - 2 4 9} \\
\text { persons }\end{array}$ & $\begin{array}{c}\text { over 250 } \\
\text { persons }\end{array}$ & Total \\
\hline Primary school & 14.3 & 17.9 & 20.6 & 19.0 & 17.3 \\
\hline Secondary school & & & & & 38.5 \\
\hline without a school-leaving exam & 38.9 & 38.7 & 41.8 & 35.8 & 32.4 \\
\hline with a school-leaving exam & 34.9 & 31.9 & 26.2 & 32.7 & 32.4 \\
\hline College, university & 11.8 & 11.5 & 11.4 & 12.6 & 11.9 \\
\hline Total & 100.0 & 100.0 & 100.0 & 100.0 & 100.0 \\
\hline
\end{tabular}

Source: KSH (2002).

Gender-specific differences in the educational level are not influenced by the size of the firms. However, the share of female employees having primary and general secondary education (without professional specialisation) is significantly higher in comparison to males. (table 2 in the Appendix)

Vocational training of employees is one of the most important tools of resolving mismatch between the labour market supply and demand sides. This mismatch is arised from impacts of continuous technological, product and service changes in the context of the global competition. To identify, evaluate and assess the performance of SME's in the field of vocational training in a particular country (e.g. in Hungary), the comparative approach seems to be an ideal methodology. However, adopting the comparative view, we have to confront such problems as the lack of up-to-date information. Therefore, the data available permit only fragmented statistical analysis on various characteristics of formal training. To cover of these difficulties we (intend to) use the following sources of information on vocational training:

1. Central Statistical Office (CSO - Hungary) (Lakatos/Linderné Eperjei 2004)

2. Continuous Vocational Training Survey (1999) (SMEs in Europe 2002)

3. Working Conditions in the Accessing and Candidate Countries (2001) (Working Conditions 2003) 
The latest comprehensive international survey (Continuous Vocational Training Survey - CVTS), which gives information about the training opportunities provided by firms to their employees was carried out in 1999. The two postsocialist economies participating in the SMALL project (Bulgaria and Hungary) took part in the CVTS. In the Hungarian case the CVTS covered $50 \%$ of the persons employed in the competitive sector representing 125600 firms. Unfortunately, the group of the micro-firms (employing less than 10 persons) did not join in the survey. Evaluating the results of the survey, we may say that there is a visible relation between the importance of the training activity and the size of the firm in Hungary. In the large firms formal training related activities are more important in comparison with the small firm. In this respect the following three categories of firms were distinguished:

- small firms (10 - 49 persons): only one third of them are organising training for their staff and an important part of them said the preparation of a ,training plan” had been unnecessary;

- medium-sized firms (50 - 249 persons): every second of them offering training opportunities for their employees and preparing a training plan in the similar rate;

- large firms (over 250 persons): an overwhelming majority of them (80\%) provides training for their staff and two thirds of them are regularly participating in the training planning activities.

In relation with the size of the firm and the training practice, we have to note that in micro-firms formal training activity is weaker than in the small firms. In addition we have to note that the small and medium-sized firms do not use ,inhouse" training facilities for formal training purposes. Therefore, they have to buy the necessary training from external sources at market price. For example, the great majority of firms (73\%) employing (from) 10 to 19 persons and offering training opportunities for their staff is exclusively using external training services. The share of external services is only $15.4 \%$ in the firms employing more than 1000 persons.

Evaluating in an international perspective, the companies' vocational training practise hours spent in CVT courses by field of training is indicating the most and the least popular training subjects in the EU-15 countries' group (e.g. Belgium, France, Italy, Portugal, Sweden and UK) and in Hungary (New Member Countries' group) and Bulgaria (Associate Candidate Country) by size category of firms in 1999. See in details tables $4 / a$ and $4 / b$. 
Table 4/a. Hours Spent in CVT Courses by Field of Training, (1999) (\% of total hours in CVT Courses)*

\begin{tabular}{|c|c|c|c|c|c|c|c|c|c|}
\hline $\begin{array}{l}\text { Size } \\
\text { category } \\
\text { of firms }\end{array}$ & EU-15 & $\begin{array}{l}\text { Bel- } \\
\text { gium }\end{array}$ & France & Italy & Portugal & Sweden & UK & $\begin{array}{l}\text { Bul- } \\
\text { garia }\end{array}$ & $\begin{array}{l}\text { Hun- } \\
\text { gary }\end{array}$ \\
\hline \multicolumn{10}{|c|}{ Accounting, finance } \\
\hline $\begin{array}{l}\text { Small } \\
(10-49)\end{array}$ & 7 & 4 & 9 & 5 & 9 & 7 & 6 & 10 & 14 \\
\hline $\begin{array}{l}\text { Medium } \\
(50-249)\end{array}$ & 6 & 4 & 5 & 7 & 2 & 6 & 9 & 8 & 15 \\
\hline $\begin{array}{l}\text { Large } \\
(250+)\end{array}$ & 5 & 8 & 4 & 5 & 2 & 10 & 4 & 1 & 9 \\
\hline Average & 5 & 6 & 5 & 5 & 3 & 8 & 5 & 2 & 11 \\
\hline \multicolumn{10}{|c|}{ Computer Science/computer use } \\
\hline $\begin{array}{l}\text { Small } \\
(10-49)\end{array}$ & 23 & 23 & 31 & 14 & 13 & 32 & 29 & 4 & 11 \\
\hline $\begin{array}{l}\text { Medium } \\
(50-249)\end{array}$ & 20 & 17 & 29 & 19 & 9 & 27 & 13 & 18 & 11 \\
\hline $\begin{array}{l}\text { Large } \\
(250+)\end{array}$ & 15 & 14 & 17 & 10 & 10 & 20 & 13 & 6 & 14 \\
\hline Average & 17 & 16 & 20 & 13 & 10 & 23 & 15 & 7 & 13 \\
\hline \multicolumn{10}{|c|}{ Engineering and manufacturing } \\
\hline $\begin{array}{l}\text { Small } \\
(10-49)\end{array}$ & 13 & 32 & 10 & 15 & 19 & 9 & 7 & 33 & 14 \\
\hline $\begin{array}{l}\text { Medium } \\
(50-249)\end{array}$ & 14 & 28 & 15 & 12 & 26 & 13 & 15 & 22 & 16 \\
\hline $\begin{array}{l}\text { Large } \\
(250+)\end{array}$ & 17 & 29 & 15 & 10 & 18 & 17 & 21 & 27 & 27 \\
\hline Average & 16 & 29 & 14 & 11 & 20 & 15 & 19 & 27 & 22 \\
\hline \multicolumn{10}{|c|}{ Environment protection, occupation health and safety } \\
\hline $\begin{array}{l}\text { Small } \\
(10-49)\end{array}$ & 10 & 6 & 5 & \begin{tabular}{l|l}
13 \\
\end{tabular} & 3 & 7 & 14 & 2 & 5 \\
\hline $\begin{array}{l}\text { Medium } \\
(50-249)\end{array}$ & 9 & 7 & 7 & 12 & 7 & 6 & 13 & 4 & 5 \\
\hline $\begin{array}{l}\text { Large } \\
(250+)\end{array}$ & 9 & 5 & 5 & 8 & 4 & 7 & 16 & 3 & 7 \\
\hline Average & 9 & 6 & 5 & 10 & 4 & 7 & 15 & 3 & 6 \\
\hline \multicolumn{10}{|c|}{ Languages } \\
\hline $\begin{array}{l}\text { Small } \\
(10-49)\end{array}$ & 3 & 5 & 3 & 4 & 2 & 1 & 1 & 9 & 8 \\
\hline $\begin{array}{l}\text { Medium } \\
(50-249)\end{array}$ & 5 & 10 & 6 & 8 & 5 & 2 & 0 & 9 & 8 \\
\hline $\begin{array}{l}\text { Large } \\
(250+)\end{array}$ & 4 & 4 & 7 & 8 & 4 & 4 & 1 & 5 & 7 \\
\hline Average & 4 & 6 & 6 & 7 & 4 & 3 & 1 & 6 & 7 \\
\hline
\end{tabular}

*Activity coverage is NACE Sections C to K and O. Source: SMEs in Europe (2002). 
Table 4/b. Hours Spent in CVT Courses by Field of Training, (1999) (\% of total hours in CVT Courses)

\begin{tabular}{|c|c|c|c|c|c|c|c|c|c|}
\hline $\begin{array}{l}\text { Size } \\
\text { category of } \\
\text { firms }\end{array}$ & $\begin{array}{l}\text { EU- } \\
15\end{array}$ & $\begin{array}{l}\text { Bel- } \\
\text { gium }\end{array}$ & France & Italy & Portugal & Sweden & UK & Bulgaria & Hungary \\
\hline \multicolumn{10}{|c|}{ Management and administration } \\
\hline $\begin{array}{l}\text { Small } \\
(10-49)\end{array}$ & 7 & 4 & 7 & 7 & 7 & 7 & 9 & 5 & 5 \\
\hline $\begin{array}{l}\text { Medium } \\
(50-249)\end{array}$ & 9 & 7 & 5 & 6 & 8 & 9 & 13 & 6 & 6 \\
\hline $\begin{array}{l}\text { Large } \\
(250+)\end{array}$ & 12 & 8 & 7 & 7 & 7 & 11 & 16 & 4 & 5 \\
\hline Average & 11 & 7 & 7 & 7 & 7 & 10 & 15 & 4 & 5 \\
\hline \multicolumn{10}{|l|}{ Office work } \\
\hline $\begin{array}{l}\text { Small } \\
(10-49)\end{array}$ & 2 & 2 & 2 & 3 & 3 & 1 & 2 & 1 & 1 \\
\hline $\begin{array}{l}\text { Medium } \\
(50-249)\end{array}$ & 3 & 2 & 1 & 2 & 1 & 1 & 5 & 1 & 2 \\
\hline $\begin{array}{l}\text { Large } \\
(250+)\end{array}$ & 2 & 3 & 1 & 3 & 1 & 1 & 2 & 0 & 2 \\
\hline Average & 2 & 3 & 1 & 3 & 1 & 1 & 2 & 0 & 2 \\
\hline \multicolumn{10}{|c|}{ Personal skills/development } \\
\hline $\begin{array}{l}\text { Small } \\
(10-49)\end{array}$ & 10 & 8 & 6 & 14 & 4 & 11 & 15 & 1 & 2 \\
\hline $\begin{array}{l}\text { Medium } \\
(50-249)\end{array}$ & 11 & 13 & 8 & 13 & 10 & 16 & 15 & 3 & 5 \\
\hline $\begin{array}{l}\text { Large } \\
(250+)\end{array}$ & 12 & 13 & 10 & 18 & 14 & 13 & 13 & 0 & 4 \\
\hline Average & 12 & 12 & 9 & 16 & 12 & 14 & 14 & 1 & 4 \\
\hline \multicolumn{10}{|c|}{ Sales and marketing } \\
\hline $\begin{array}{l}\text { Small } \\
(10-49)\end{array}$ & 10 & 8 & 7 & 6 & 14 & 13 & 12 & 4 & 14 \\
\hline $\begin{array}{l}\text { Medium } \\
(50-249)\end{array}$ & 8 & 4 & 8 & 7 & 12 & 10 & 5 & 10 & 11 \\
\hline $\begin{array}{l}\text { Large } \\
(250+)\end{array}$ & 9 & 9 & 11 & 9 & 8 & 7 & 8 & 2 & 8 \\
\hline Average & 9 & 7 & 10 & 8 & 9 & 9 & 8 & 3 & 9 \\
\hline \multicolumn{10}{|l|}{ Others } \\
\hline $\begin{array}{l}\text { Small } \\
(10-49)\end{array}$ & 15 & 8 & 20 & 19 & 26 & 12 & 5 & 31 & 26 \\
\hline $\begin{array}{l}\text { Medium } \\
(50-249)\end{array}$ & 15 & 8 & 16 & 12 & 20 & 9 & 12 & 19 & 21 \\
\hline $\begin{array}{l}\text { Large } \\
(250+)\end{array}$ & 15 & 7 & 23 & 22 & 32 & 10 & 6 & 52 & 17 \\
\hline Average & 15 & 8 & 23 & 20 & 30 & 10 & 6 & 47 & 21 \\
\hline
\end{tabular}

Source: SMEs in Europe (2002). 
Earlier, we stressed the relation between the vocational training and the company size in the Hungarian context: only one third of the small firms but four fifth of large firms are organising vocational training course for their employees. This pattern will be more differentiated if we compare the firm level vocational training by subjects of training and from international perspective. Evaluating the data presented in tables $4 / \mathrm{a}$ and $4 / \mathrm{b}$, the following patterns of the company training practice should be identified.

Comparing the EU countries participating in the SMALL project, we may say that among the ten fields of company training the most popular training subjects were (in ranking order): „computer science and computer use” (17\%), „engineering and manufacturing” (16\%), ,personal skills/development” (12\%) and „management and administration” (11\%). „Computer science and computer use" as a training subject was higher than the average share (over $30 \%$ ) in the training activities of the French and Swedish firms. Evaluating the effects of the size category of business organisations, we may say that in the small and medium-sized firms ,computer sciences and computer use” plays a more important role in the firm-level training than in the large firms. In a lesser degree, the similar pattern was found in training subjects such as ,accounting, finance”, „environmental protection” and „language”. However, in the case of „engineering and manufacturing” (16\%), ,personal skills/development” (12\%) and „management and administration” (11\%); all three were more favoured by large firms than by small ones.

Evaluating the company training practice in the Bulgarian and Hungarian firms, we found the following patterns: in both countries the training subject of „engineering and manufacturing” (Bulgaria: $27 \%$ and Hungary: $22 \%$ ) occupied the first place, followed by „,computer science and computer use"(Bulgaria: $7 \%$ and Hungary: 13). Beside the similar position of these two training subjects, significant differences were found in their share within the total hours spent in CVT courses. For example the share of ,engineering and manufacturing” was 27 hours in Bulgaria and in Hungaryonly 22 hours (were spent on such kind of training). In the case of the „computer sciences and computer use” Hungarian firms spent more (13 hours) than Bulgarian ones ( 7 hours). In addition, we have to mention that in the Bulgarian case, small firms spent more hours on formal training than larger ones. In the Hungarian context the opposite pattern was identified.

In the third and fourth positions the following training subjects were identified in the two post-socialist economies: in Bulgaria „language" (6 hours) and „management and administration” (4 hours), in Hungary ,accounting and finance" (11 hours) and „sales and marketing” (9 hours). Except the „others” item, Hungarian firms (are )spend (ing) more hours on various forms of formal vocational trainings than the Bulgarian firms. 
Comparing the company training practice of the two post-socialist economies participating in the SMALL project with the EU - 15 country group, the general position of the first shows an interesting difference between Bulgarian and Hungarian firms In the cases of „engineering and manufacturing”, „computer science and computing”, ,environmental protection, occupational health and safety", large Hungarian firms (are) spend(ing) more hours than small and medium-sized firms. In the case of Bulgaria, the size effect on the company level vocational training is much weaker or not visible.

Another international survey on the working conditions (2001) was carried out in the so-called „Acceding and Candidate Countries" (ACC), including Bulgaria and Hungary (Working Conditions 2003). During this survey, using the representative sample of workers (people in employment, both employees as well as self employed), 12000 people were interviewed. Similarly to the Hungarian experiences of the CVTS, large firms offer better opportunities (79 $\%)$ than micro firms, employing less than five persons $(60 \%){ }^{4}$ With age, workers have less opportunities to participate in learning, especially those over 55. Similarly to this circumstance, women have less opportunities to learn (62 $\%)$ than men $(67 \%)$. Concerning the so-called ,skill matching", most interviewees $(89 \%)$ reported that their skills had matched the requirements of the job. Skill matching is even better in the large firms where an overwhelming majority of employees $(93 \%)$ reported that their skills had matched the demand of the job. Finally, the skill gap is decreasing in the case of the older workforce: the skill gap is higher among the younger workers $(15 \%$ in the age group from 15 to 14 year old) than among the older ones (9\% in the age group of 55+). (Note: Due to the fact that the skill match was not the primary objective of the working condition survey, we do have to use these data carefully.)

There are significant differences concerning the opportunities to participate in company training programs. „On average, $24 \%$ of all workers (EU-15: $34 \%$ ) have undergone training over the past 12 months. This ranges from the Czech Republic (48\%), Slovenia (35\%) and Slovakia (39\%) at one extreme to Bulgaria (19\%) and Romania (12\%) at the other employees only, on average 27 $\%$ report that they received training from their companies in the past 12 months (EU - 15: 34 \%)" (Working Conditions 2003 - see table 5).

The share of employees 'participation in training during the last 12 months and the average length of training indicate rather different patterns. For example, comparing the share of employees participating in the training in the last 12 months, the Czech Republic, Slovakia and Estonia are on the top of the ranking. In contrast, results of comparison of the average length of training produced another hierarchy of the ACC countries. In this case, Malta, Cyprus and

4 According to the latest SME survey on the professional development, fewer than $40 \%$ of small firm undertake formal training in a regular basis (Moules 2004b). 
Hungary have the best positions. However, the dominant field of training is the (b?) obligatory training on ,health and safety regulations" (in the workplace).

Table 5. Training of Employees in the ACC: 2001

\begin{tabular}{|c|c|c|}
\hline \multirow[t]{2}{*}{ Countries } & \multicolumn{2}{|c|}{ Indicators of Training } \\
\hline & $\begin{array}{l}\text { Employees who received } \\
\text { training over the past } 12 \\
\text { months }(\%)\end{array}$ & $\begin{array}{l}\text { Average length of training } \\
\text { (number of days) }\end{array}$ \\
\hline Bulgaria & 12 & 2.0 \\
\hline Romania & 17 & 3.7 \\
\hline Lithuania & 24 & 5.4 \\
\hline Hungary & 25 & 6.8 \\
\hline Cyprus & 25 & 7.9 \\
\hline Latvia & 26 & 4.3 \\
\hline Poland & 24 & 2.8 \\
\hline Malta & 29 & 9.2 \\
\hline Estonia & 34 & 4.5 \\
\hline Slovenia & 26 & 4.7 \\
\hline Slovakia & 40 & 2.6 \\
\hline Czech Republic & 51 & 3.5 \\
\hline $\mathrm{ACC}-12$ & 27 & 3.7 \\
\hline
\end{tabular}

Source: Working Conditions (2003)

\section{Knowledge (Competence) Developments and Use Practice in (the) SMEs}

In relation with knowledge development, the CVTS (1999) differentiated between „traditional” and „non-traditional” training. In the case of the first category, employers are organising training for their staff within the firm (in house training) or buying this service from outside (from external trainers). In the case of „non-traditional" training, the following forms of knowledge developments or transfer were distinguished:

1. Training on the Job (O.J.T.)

2. Training via Job Rotation

3. Quality Control Group

4. Self Development

5. Conferences

Table 6 presents the distribution of „traditional” vs. „,non-traditional” training by size category of firms in Hungary.

More than one fifth $(23.9 \%)$ of the firms participating in the CVTS offered their employees training of traditional form and almost one third of them (30.4\%) organised non-traditional forms of training. We may say that in all size 
categories of firms, more business organisations organised non-traditional forms of training in comparison to the traditional ones. The importance of training is varying by size category of firms. While one fifth (19.4\%) of small firms organise traditional forms of training, large firms (over 1000 persons) are organise the same form of training at a four times higher rate $(79.4 \%)$. An almost similar pattern is visible in the case of non-traditional forms of training. Evaluating the firm level training activities by sectors of the national economy, we may say that in the financial and insurance service sector the share of company training is from 1.5 to 3 times higher than in the national average. In contrast to the national pattern, , the share of the traditional form of training in this sector is slightly bit higher than the non-traditional form of training $(69.4 \%$ versus $66 \%$ ).

Unfortunately, no comparative data exist concerning the dimensions mentioned above. The lack of information should partly be completed by the information collected by the „European Network for SME Research - ENSR Enterprise 2002 Survey (Competence Development in SMEs 2003). According to the results of this survey, the most popular method to develop knowledge or competence is to visit expos and trade fairs. „These visits can be regarded as an important method for developing an SME`s internal competencies. Thus enterprise in general and SMEs in particular learn from these exhibitions and trade fairs the latest technological and/or market developments in their specific branch of industry. Expos and trade fairs where new technologies, machines and production processes are exposed and demonstrated are particularly popular amongst SMEs. Both entrepreneurs and employees can thus get acquainted with these new developments in an efficient and effective way. In a limited period of time (one or two days) they can get information about new developments in their own line of business, as well as in those of their suppliers and clients ... In addition, these expos and trade fairs assist SMEs to take part in different activities such as seminars, networking activities, counselling, etc." (Competence Development in SMEs 2003). Table 7 gives an excellent overview on the use of various competence developing methods by the size of firms in the EU - 19 countries. ${ }^{5}$

The data presented in table 7 indicate the strong relation between the size of firms and the use of various methods for developing the competence (base) of their human resources. Not surprisingly, in all fields of knowledge or competence development large firms have an advantage (oder: a better position). In this relation we have to mention that highly developed firm-specific training

5 EU - 19 countries composed by EU - 15 plus Iceland, Liechtenstein, Norway and Switzerland or Eurpean Economic Area (EEA) and Switzerland. 
in the large firms is the tool to keep personnel and a strategy against poaching their staff through developing corporate culture."

Table 6. Traditional and Non-traditional Forms of Company Training in Hungary in 1999

\begin{tabular}{|l|c|c|}
\hline \multirow{2}{*}{$\begin{array}{l}\text { No. of persons employed } \\
\text { birms }\end{array}$} & $\begin{array}{c}\text { Traditional Form of } \\
\text { Training }\end{array}$ & $\begin{array}{c}\text { Non-traditional Form of } \\
\text { Training }\end{array}$ \\
\cline { 2 - 3 } & \multicolumn{2}{|c|}{ Share in the Number of Firms (\%) } \\
\hline $\begin{array}{l}\text { Small firms }(10-49 \\
\text { persons) }\end{array}$ & 19.4 & 26.3 \\
\hline $10-19$ persons & 17.1 & 23.6 \\
\hline $20-49$ persons & 23.5 & 31.2 \\
\hline $50-249$ persons & 37.1 & 41.3 \\
\hline $250-499$ persons & 58.6 & 65.5 \\
\hline $500-999$ persons & 67.9 & 77.2 \\
\hline $1000+$ persons & 79.4 & 84.7 \\
\hline Country average & 23.9 & 30.4 \\
\hline
\end{tabular}

Source: A gazdasagi szervezetek sajat munkavallaloik szamara biztositott kepzesek az (1999).

Beside the visible focus of large firms on the use of various tools of knowledge development, table 7 calls the attention to various things. Beside the well-known pattern of stronger priority of training in the large firms in comparison to the micro- and small firms, it is necessary to call the attention to the particular importance of the informal dimension of training in the SME sector. For example, the share of the firms declaring the lack of formal training was higher in the category of micro- and small firms thanin the category of medium-sized and large firms. This situation indicates the underdevelopment of the systematic and formal training practice in the SMEs. However, the informal practice of the „tacit”, „non-coded” knowledge/competence development and transfer are present in these firms, but the assessment of their impact requires qualitative research tools, e.g. case studies. The next section of the report is focusing on the training experiences learned from the company case studies.

Table 7. Share of SMEs Using Different Methods for Developing the Competence Base of their Human Resources in the Last Three Years, by Firm size, Europe- 19 in 2001

\begin{tabular}{|l|l|l|l|l|}
\hline \multirow{2}{*}{$\begin{array}{l}\text { Methods of competence } \\
\text { development }\end{array}$} & \multicolumn{3}{|l|}{ Number of Employees } & Average \\
\cline { 2 - 5 } & $0-9$ & $10-49$ & $50-249$ & \\
\hline Visits to Expos/trade fairs & 57 & 70 & 78 & 58 \\
\hline $\begin{array}{l}\text { Courses/seminars/conferences } \\
\text { provided by own personnel }\end{array}$ & 19 & 38 & 54 & 21 \\
\hline
\end{tabular}

6 The development of specific corporate cultures, which can be 'learned' only through prolonged training and subsequent experience (Crouch 2004). 


\begin{tabular}{|c|c|c|c|c|}
\hline $\begin{array}{l}\text { Courses/seminars/conferences } \\
\text { provided by external trainers }\end{array}$ & 39 & 56 & 70 & 41 \\
\hline Study visits & 17 & 22 & 41 & 18 \\
\hline $\begin{array}{l}\text { Job rotation (in-house or in } \\
\text { other firms) }\end{array}$ & 8 & 17 & 29 & 9 \\
\hline $\begin{array}{l}\text { Tutor/mentoring activities for } \\
\text { staff }\end{array}$ & 10 & 20 & 27 & 9 \\
\hline $\begin{array}{ll}\text { Promote reading } & \text { of } \\
\text { professional literature } & \end{array}$ & 36 & 39 & 58 & 35 \\
\hline $\begin{array}{l}\text { Co-operation with consultants } \\
\text { and advisors for developing } \\
\text { internal competence }\end{array}$ & 21 & 32 & 39 & 22 \\
\hline $\begin{array}{l}\text { Meetings amongst personnel } \\
\text { for knowledge exchange }\end{array}$ & 32 & 46 & 56 & 33 \\
\hline Other activities & 4 & 5 & 5 & 4 \\
\hline Do not know/no answer & 0 & 0 & 0 & 0 \\
\hline $\begin{array}{l}\% \text { of SMEs not involved in any } \\
\text { of the suggested methods }\end{array}$ & 20 & 9 & 4 & 19 \\
\hline $\begin{array}{l}\% \text { of SMEs not having formal } \\
\text { training activities }\end{array}$ & 61 & 44 & 30 & 59 \\
\hline $\begin{array}{l}\text { Average number of methods } \\
\text { applied by enterprises }\end{array}$ & 3.1 & 3.8 & 4.8 & 3.1 \\
\hline
\end{tabular}

Source: Competence Development in SMEs (2003).

Finally, in relation to the data presented in table 7 , it is necessary to mention that the important distinction made between „formal"and ,informal” forms of training and competence development is still narrow. This means that the socalled „folio" knowledge and competence development does not cover the great variety of forms of knowledge transfer and acquisition. For example, the various forms of organisational innovations (e.g. multi-functional design teams, projecttype based firms' cooperation etc.) like visiting fairs and participating in various forms of study tours etc. are not only an important source of knowledge transfer but also facilitators of developing individual and collective ,absorptive capacities" of the firms concerned.

\section{Lessons from the Hungarian Case Studies: Various Types of Skill-Equilibrium}

Hungarian company case studies were organised in the sectors of tourism, clothing industry and interactive media. Besides adopting the selection criterion of case studies by the research consortium (SMALL), the reason of selecting an appropriate sector was the following: the clothing industry represents the wellknown manufacturing activity characterising the industrial age, where work is organised on the principles of fordism or new-fordism. The other industrial age sector selected was the tourism which belongs into the category of the fastest growing service sector in the country. An interactive media firm belongs into the 
sub-category of the ICT sector which has many characteristics of the "new” skill demands due to the first stages of growth. Due to this cycle of sector development - i.e. the lack of its maturity - clear patterns of skill demands and specified requirements have not yet been developed. This period of development, settled and approved patterns of skill use have not yet been legitimated by social actors concerned (educational and training institutions, firms, customers, chambers etc.). In this situation, if coding skills and knowledge requirements are missing extensively, it will be extremely difficult to design and organise formal training courses. However, knowing the company practice of using, sharing and developing non-formalised (tacit) skills and competences may help us to better understand the process of emerging new paradigms of knowledge use in the rapidly growing information technology sector.

Adopting the briefly presented selection criterion, the Hungarian case studies were carried out in manufacturing (i.e. clothing industry), service sector (i.e. tourism) and ICT (i.e. interactive media). ${ }^{8}$

Evaluating the „skill” and „knowledge" use, development and sharing practices in the firms investigated in the three sectors mentioned above, we have to differentiate between the "low-skill equilibrium” and „high-skill equilibrium” firms. Firms belonging into the first category (e.g. clothing company, tourist firm) (would) have to compete almost exclusively on price and participate in the "cost cutting spiral" that (would) block them to invest into company training.

The opposite skill development strategy, called „high-skill equilibrium”, in this case, where the national level of Vocational Education and Training (VET) is strong, firms are able to produce high value added products and services and are able to keep their national and international market position through further investments in the company level training. ${ }^{9}$

7 To illustrate the high growth character of the ICT sector, it is interesting to note that between 1999 and 2000, the growth rate of this sector exceeded with $6 \%$ the average growth rate of the national economy in Hungary (Csizmadia 2004).

8 See Table 5 and 6 in the Appendix as well as the Notes at the end of the text.

9 Finegold/Sockice (1988) made a distinction between the „high” versus „low-skill equilibria" which indicated that the national sysetems of Vocational Education and Training (VET) would lock countries into one or the other path of development. In our interpretation, the distinction of "low-skill equilibrium" vs. ,high-skill equilibrium” is useful classification of training practice not only national but, firm level, too. 


\section{Clothing and Tourist Firms: the Cases of ,Low-skill Equilibrium"}

In the case of the clothing sector, three higher educational institutions (i.e. Technical College of Budapest, Technical University of Budapest and College of Applied Arts) are the key suppliers of the highest skills. Numerous secondary and basic level vocational training institutions are participating in the skill supply. In addition, nationally accredited training institutions that are operating within the framework of the labour market programme provide clothing industry related skills One of the most important weaknesses of the knowledge supply is the lack of ,practical skill”. Therefore, the newly recruited workers have to spend years with on-the-job training (OJT) to gain the necessary routine and precision. In this relation, it is necessary to mention that the „Hungarian Society of Textile Technology and Science" organises accredited further education/ training for adults. Besides the professional training, owners/managers of SMEs in this sector have not the necessary managerial and marketing skills. In this relation it is worth quoting the opinion of the Head of „Foundation for Supporting Entrepreneurship"(FSE), according to whom the entrepreneurial skills are lacking in the small and medium-sized firms in the clothing or garment firms:

„Owner/managers usually looking for money oriented seminars because they think that this is the essence of an enterprise. But, with the progress of their activities, it turns out that not the money is not the most important factor or at least not the only important factor for the success of their business. We (i.e. the „FSE”) believe that prosperous business has three bases. First is the expertise, the second is good managing skills and the last is the sufficient entrepreneurial skill" (Simonyi et al. 2004).

In the company investigated, all employees have more than 20 year professional experiences in both men and lady's cloths (wears). Therefore, they are able to manufacture high quality products directly to the boutiques. The owner/manager in this small firm graduated from the "Garment Trade Technical Highs School”, then she spent almost a decade at the „Blue Danube Clothes Saloon” in Budapest. During the first two years she had been working as a sewer and then as a tailor for another six years. In her firm, beside her managerial duties she works as dress designer. She develops her knowledge on the job and is using the ideas derived from international fashion magazines. Her model designing activity - carried out at home and not in the shop - is based on these types of knowledge. According to her, due to the small size of the firm and to the low priority of the growth of the firm, the need of a new knowledge generation and any kind of training is not necessary neither for her nor for her employees:

„There are many kinds of training, for example modelling or stylist one, but I never thought about it, because there is no need for it" (Simonyi et al. 2004). 
The firm called „Tours Co. Ltd.Kft” is a small firm operating in the tourist sector. Its work organisation is rather simple, „everybody is doing everything”. The work carried out by employees is not specialised and does not need a degree of higher education. The job structure varies and offers interesting work in comparison to the routine and standardised jobs available in the large tourist companies. Presently only two persons are attending higher education courses, instead of financial help the firm gives them working time reduction. Among the owners of the company only the owner/manager attends an ICT course. The lack of organisational promotion has negative impact on the training activity in the company. However, the so-called „emotional” and „soft” skills (e.g. empathetic capacity, communication skill etc.) are highly necessary. These kinds of skill are the results of the on the job training. A particular importance of O.J.T. is that it will be unnecessary to organise formal training in the firm. According to the owner of the company, ,the school is supplying only the basic elements of the necessary knowledge, only those employees are able to keep the job, whose personality is adequate and who are able to mobilise practical skills acquired in the course of work" (Owner/manager). (Schwartz/Illéssy 2004)

The other important source of knowledge and motivation of employees are the so-called "study tours", which are organised by large hotel owners. A tourist company is selling the services of the hotels visited to its own clients. Better selling practice requires not only the perfect knowledge of the services offered by the hotels but also highly motivated employees to sell them. Both owners/managers and employees of „Tours Co. Ltd. Kft.” are participating in such kind of study tours:

„I offer more enthusiasm for our customers such hotels or holiday resorts, which are known for me and for my staff. Study tours are excellent occasions for both network building and to improve our communication skill in foreign languages" (owner/manager) (Schwartz/Illéssy 2004) (and represents a form of „quality assurance" by the tourist company).

In addition to the knowledge or skill development function of study tours, it is necessary to mention their incentive role of keeping employees at the firm.

„We can not pay high wages, therefore, the opportunities to participate in study tours and to visit other countries is one of the most important motivating tools of employees. Unfortunately, when our employees' needs and ambitions to travel abroad have been satisfied, they often leave us" (Schwartz/Illéssy 2004). 


\section{Fluid and Innovative Character of Work in the Interactive Media Firm (ICT Sector): Example of the „High - skill Equilibrium"}

Evaluating the level of formal educational level, we may say that in the ICT sector - in its interactive media sub-sector - the share of education labour is higher than the national average. See in detail table 8 .

Firms operating in the interactive media sub-sector of the ICT sector are characterised among others by the specialised and quickly changing knowledge at almost all points of the value chain of this type of activity. (In selecting a company case study in this sub-sector, we used the following definition for the interactive media activity: „Interactive media production technically means the production of design and programmes for digital, interactive media like the Internet, intranet and for off-line media like CD-ROMs and DVDs. Multimedia, digital media, web-production and Internet consulting are other names for these and similar activities" (Augustsson/Sandberg 2002).

Table 8. Share of Employees by he Level of Education, 2001 (\%)

\begin{tabular}{|c|c|c|c|c|c|c|}
\hline \multirow[t]{2}{*}{ Sector } & \multicolumn{6}{|c|}{ Educational level } \\
\hline & $\begin{array}{l}\text { Lower } \\
\text { than } \\
\text { primary }\end{array}$ & Primary & $\begin{array}{l}\text { Secondary } \\
\text { vocational }\end{array}$ & $\begin{array}{l}\text { General } \\
\text { secondary }\end{array}$ & $\begin{array}{l}\text { Tertiary or } \\
\text { higher } \\
\text { education }\end{array}$ & Total \\
\hline $\mathrm{ICT}$ & 0.1 & 4.0 & 5.0 & 42.4 & 48.2 & 100.0 \\
\hline $\begin{array}{l}\text { Nation } \\
\text { (National } \\
\text { Labour } \\
\text { Force } \\
\text { data) }\end{array}$ & 0.8 & 19.6 & 28.8 & 32.4 & 18.3 & $? ? ?$ \\
\hline
\end{tabular}

Source: National Statistical Office (2002).

For the "developers", the primary source of knowledge is the expertise. The Internet related knowledge means quickly obsolescent knowledge even inside the IT sector. There is a shortage of skills in this field because the knowledge supply can not meet the quickly changing skill demand. In this relation, it would be more appropriate to use the term of "learning economy" instead of „knowledge economy”. I share the following position of the DRUID group: „In various contexts we have introduced an interpretation of what actually takes place in the economy under the term 'the learning economy' (Lundvall Johnson 1994, Lundvall - Nielsen 1999). The intention is that the term should mark a distinction from the more generally used term 'the knowledge-base economy'. The learning economy concept signals that the most important change is not the more intensive use of knowledge in the economy but rather that knowledge (becomes absolute more rapidly than before) changes absolute. Therefore it is imperative that firms engage in organisational learning and the workers constantly attain new competencies. This can be illustrated by a 
reference in a recent report from the Danish Ministry for Education to a German source which claims that half of the skills a computer engineer has obtained during his training will have become obsolete one year after the exam has been passed, while the 'halving period' for all educated wage earners is estimated to be eight years." (Ministry of Education 1997)

„Nowadays we are looking for PHP and HTML editors, and it is not really a knowledge you can learn at school. It depends on how much time you spend on it at home", (Senior developer) (Csizmadia 2004).

Beside the lack of the personnel who is developing his or her skills, another problem is the lack of "social skill”, for example the ability to „work in team" and to be intermediary between employees working in the project and the clients of the project. The following quotations from interviews illustrate which type of knowledge is lacking on the skill supply side of the interactive media activity. „Senior developers" are complaining of the strong individualistic and weak team-work friendly attitudes of employees:

„Most of the problems are caused by problem-solving skills and creativity. The worker can't see the differences between collective and individual work. There are two cases: one of them is when the worker just stops, waits, and the work doesn't go on. The other is when the worker just works isolated and he or she produces something completely useless" (Csizmadia 2004).

Due to the fact that the client is playing a crucial role in the interactive media project, the satisfaction of clients has strong impact on the success rate of the project. The content of the critical role played by the so-called „knowledge broker" is described in the following interview quotation:

„Usually the client is not a computer expert, but he or she thinks he or she is, and it is terribly difficult to convince him or her about what is good for him or her. There are two possible clients: the first one wants a homepage because it is a ,cool thing”, everybody has one. In this case our creators find out the purpose of the homepage, usually the clients accept it. The other one tinkers away at the small things, he or she doesn't like this like that, wants the registration on another way, and it is very difficult to convince him or her. Here is the point where everything depends on the ability of the project manager" (Csizmadia 2004).

Summarizing the necessary skill combination in the interactive media firms, we may say that the mix of professional/technical and social skills is necessary. Employees can not study this skill-mix in the formal educational and training institutions. Only in the forms of "learning by doing” or „on-the-job training” could they develop, share and use these types of skills. On the importance of OJT, the firm's „Media manager” said the following:

„What we use, one can't learn at the secondary school and colleges. What we know it took one hard year to learn at work. If the material you possibly are able 
to know takes $100 \%$ than we know $80 \%$. We could improve this, for example with foreign and server technology, but really we are the only ones who could do the training both for the clients and for the high school students." (Csizmadia 2004).

Managers viewed OJT as the most important tool of competence development, in spite of the fact that the company is offering significant resources on formal training (in terms of money), the dominant form of the ,project type” work organisation limits the scope of this type of competence formation. Due to time shortage of competence development (production or work is organised on the bases of short-time projects using team-work and due to the ad hoc forms or lack of formal competence development programme, the required competence development is matter of individual responsibility of workers. (Due to the extremely young age of this micro- and small firms in this sector, both employers' as well as employees' interest representative associations are completely missing. In this context, presently, no social (collective) actor monitors or supervises the skill and competence development process in the interactive media sub-sector.) However, due to the extremely intense competition and the above mentioned shortening of 'halving period' of employees knowledge, employers in the interactive media sector are aware of the necessity to organise collective the knowledge development and via this to develop absorption for the 'smooth' transfer of external knowledge.

\section{Concluding Remarks}

International comparative and up-to-date data on company level training and competence development are deficient. The latest EU-level survey partly covered the Candidate Countries - who are EU members since the $1^{\text {st }}$ of May 2004 - was carried out at the end of the 1990`s as the well-known CVT survey. However, in the 1999's CVTS called the attention to the asymmetric pattern of training subjects between the EU-15 country group and the group of NMC/ACC (Bulgaria and Hungary). In the first group of the country IT-skill-related dominated and the second group of country the „old economy” training like engineering occupied the leading position. The latest comprehensive survey on the working conditions - including company training practice - was carried out at the beginning of this century (2001), but training was treated as a relatively minor issue within the section of ,work organization". Unfortunately, the data of the European level working condition survey are aggregated and, therefore, data analysis by (the) size category of firms is impossible.

To overcome knowledge deficiency originated from the lack of international comparative data, we may use data as a ,proxy indicator" of a country, which is 
playing a „benchmarking role” in the developing SME sector (e.g. Denmark ${ }^{10}$ ). Using this method, we may say that ,insufficient budget" and „lack of time" are the most important barriers in all size categories of firms within the SME sector.

In relation with the „lack of knowledge of choices of courses”, it is necessary to call the attention to the limited information absorption capacity and to the lack of contacts with the possible knowledge source of entrepreneurs. In this relation, we would like to stress that in the SME sector, the "difficulties to identify valuable source of competence" for training represent a more important barrier than the diagnosis of their ,skill needs".

The international (or national) surveys are almost exclusively using quantitative methods and focusing on the formally identifiable characteristics of the training (e.g. hours spent on training by subject, existence of training planning etc). Generally, these surveys are not appropriate research methods to identify and describe the informal dimension and process character of the company training and competence development as well as knowledge sharing practice. According to the strategies and market position of SMEs in a particular sector, a variety of forms of training and knowledge development is taking place, even in the firms which are not participating in the design/organisation of formal training activities surveyed by national and international dimensions. In this relation we share the following opinion: „Small businesses do develop people. But this is often missed in surveys because it is done on an informal basis, within the company" (Moules 2004).

The experiences of the case studies call the attention to the key role of strategy and types of activity of the SMEs investigated in a particular sector. It is impossible to make a balanced diagnosis on the training practice of firms investigated without analyzing both internal and external context of the SMEs surveyed. For example, in the case of the „clothing” and „tourist" companies, where expertise and knowledge are available for the survival of the firm, the socalled „low-skill equilibrium" model of skill use is suitable for these cases. Formal training activities are missing and the main sources of the necessary skills or competences are such external forms of knowledge transfer as hiring skilled labour from the labour market or visiting clients. However, these forms of knowledge transfer are not fully sufficient for the smooth operation of the firms, for example in the "tourist" company the so-called ,,aesthetic" or „softskills" are still missing. In relation with the „low-skill equilibrium” model, it is

${ }^{10}$ For example, in Denmark, factors like ,insufficient budget” or „lack of time” represent almost the same weight in micro-, small and medium-sized firms. However, the micro and small firms had weaker position in comparison with medium-sized or large firms in fields such as „no relevant course on the market”, „lack of knowledge of the choices of courses” or "lack of motivation of the employees" and "lack of motivation of the management" (see table 3 in the Appendix). 
worth mentioning that the owner's/manager's negative attitude to change represents an important barrier for competence development activities. SME entrepreneurs are often reluctant to invest in their employees bearing in mind the possibility of skilled labour being ,poached" by competitors, which in contrast foster SMEs to „buy in” skilled employees rather than to invest in developing their in-house competence base. In other words, this is the well-known phenomenon of the „....competence paradox, which means that the enterprises which invest in their employees' competence development simultaneously increase the possibility that these employees will leave the company." (Competence Development in SMEs 2003). This phenomenon of „competence paradox" does not only characterise the training practice of the Hungarian SMEs operating in the clothing or tourist industries, but the same pattern was also identified by the chair of the British „Federation of Small Business” (FSB): „Some small business owners are defensive because they think development of people means losing people because they become ambitious. They tend to buy in the talent if there is a business case" (Moules 2004).

In the ,interactive media firm”, the skill use practice was characterised by the „high-skill equilibrium" model. Due to the fact that this firm is operating in the knowledge economy sector, the fast technology development and the key roles of customers in the project type work the employees have to continuously develop both their professional as well as social skill. Due to the fact that the formal skill or knowledge supply is inadequate or extremely expensive, the role of developing social mechanisms facilitating the share of ,tacit knowledge" and the creation of „social skill” (e.g. to work smoothly in the team) have decisive importance.

A common pattern identified in all case studies carried out in the three sectors is that SME owners/managers are too concerned about the daily business demands and pay less attention to the development of new soft (e.g. communicational, managerial etc.) and professional skills. Benefits of these skills will be gained only several years later but in the present business environment entrepreneurs are eager to follow their short term business interests and try to avoid any investment where benefits might only be gained several years later. Due to the low priority of investment in knowledge and competence development, it is not surprising that the Hungarian firms - especially those which are belonging into the categories of small and medium-sized companies - in the fields of process and product innovations are legging behind the EU - 15 countries (see table 4 in the Appendix).

\section{Notes}

Each company case study is composed by the following building blocks: 
1). Brief presentation of the sector, using statistical data base and secondary documents analyses and locating the firms selected into the national economic context of the country.

2). Interviews with the stakeholders responsible for the development of the sector and various issues playing key roles in the sector position both in the economy and the society (e.g. National Foundation Supporting Entrepreneurs, Hungarian Society of Textile Technology and Science, Trade Unions in the Textile and Clothing Industry, National Association of IT Entrepreneurs, Budapest Chamber of Trade and Industry, National Office of Tourism etc.) aimed to put into the relevant socio-economic contexts of the activity in the selected sector.

3). At firm level, according to the size and complexity of business organisations, firm owners, managers and employees were interviewed. Interviews were carried out repeatedly, due to the time pressure of the persons interviewed and due to the changes into the context of the firms investigated.

\section{References}

Adler, P. (2004): Skill Trends Under Capitalism and the Socialisation of Production, In: Warhurst, C./Grugulis, I./Keep, E. (eds.): The Skills that Matter, London: Palgrave McMillan, 242-260.

A gazdasági szervezetek saját munkavállalóik számára biztosított képzések az 1999. évben, I. - II. Kötet, (Training in Business Organizations for Their Employees in 1999), Budapest: Foglalkoztatáspolitikai és Munkaügyi Minisztérium - Központi Statisztikai Hivatal.

Augustsson, F./Sandberg, A. (2002): Time for Competence? Competence Development among Interactive Media Workers, Stockholm: The Natonial Institute for Working Life, 9.

Argyris, C. (1993): Knowledge for Action: A Guide to Overcoming Barriers to Organizational Change, San Francisco: Jossey Bass Publishers, in: Competence Development in SMEs (2003).

Bolton, S.C. (2004): Conceptual Confusions: Emotion Work as Skilled Work, In: Warhurst, Ch./Grugulis, I./Keep, E. (eds.): The Skills that Matter, London: Palgrave - McMillan, 19-37.

CD - Jogász ${ }^{\circledR}$ 2.20. - Hatályos Jogszabályok Gyüjteménye, (Collection of Valid Legal Rules in Hungary), 2004/06.

Competence Development in SMEs (2003): Brussels: Observatory of European SMEs, No.1, www.europa.eu.int/comm/eurostat/.

Crouch, C. (2004): Skill Formation Systems, in: Ackroyd: Oxford Handbook of Work and Organization, Oxford: Oxford University Press, 101.

Csizmadia, P. (2004): The Kowalsky Co. Company case study - ICT (Interactive media) (SMALL Project) Budapest: Institute of Sociology - Hungarian Academy of Sciences. 
Darr, A. (2004): The Interdependence of Social and Technical Skills in the Sale of Emergent Technology, In: Warhurst, C.-/Grugulis, I./Keep, E. (eds.): The Skills that Matter, London: Palgrave - McMillan, 55-71.

Finegold, D./Sockice, D. (1988): The Failure of Training in Britain: Analysis and Prescription, Oxford Review of Economic Policy, 4/3, in: Crouch, C. (2004): Skill Formation Systems, in: Ackroyd: The Oxford Handbook of Work and Organization, (Frist proof), 105.

Grugulis, I./Warhurst, C./Keep, E. (2004): What's Happening to 'Skill'?, In: Warhurst, C./Grugulis, I./Keep, E. (eds.): The Skills that Matter, London: Palgrave - McMillan, 1-18.

KSH Labour Force Survey (2002), in: Melles/Katalin (2004): The Economic and labour market characteristics of small and medium business from the 1990s until today, LEONARDO Community Vocational Training Action Program, WP 2 - WT 1, Statistical Analysis, Budapest: Institute of Sociology- Hungarian Academy of Sciences, 18.

Lakatos, J./Linderné Eperjei, E. (2004): A kis- és középvállalatok néhány emberi erőforrás jellemzője, (Some Human Resource Characteristics of the SMEs), EU SMALL Projekt, Project coordinator: Makó Cs., Budapest: Institute of Sociology - Hungarian Academy of Sciences.

Makó, C./Nemes, F. (2003): The Transfer of Managerial Competence: A Neglected Dimension in the Post-Acquisition Process, in: Makó, C./Warhurst, C./Gennard, J. (eds.) (2003): Emerging Human Resource Practices, (Development and Debates in the New Europe), Budapest: Akadémiai Kiadó, 105-142.

Makó, C./Simonyi, Á. (2003): A munka és a párbeszéd új paradigmái, (Changing Paradigms in Work and Social Dialogue), Budapest: Országos Foglalkoztatási Alapítvány (National Employment Foundation).

Melles, K. (2004): The economic and labour market characteristics of small and mediumsized business from the 1990s until today, Leonardo Community Vocational Training Action Programme, WP 2 - WT 1, Project funded by the European Community under the „Leonardo Programme”, Contract no. 2003-3448/001-001-LE2-51-OREF - Project coordinator: Makó, Cs. Budapest: Institute of Sociology - Hungarian Academy of Sciences.

Ministry of Education (1997), in: Nielsen, P./Lundvall, B.-A. (2003): Learning Organizations and Industrial Relations, DRUID Working Paper No 03-07, http://www.druid.dk/wp/pdf_files/03-07.pdf).

Moules, J. (2004a): Finding the time and money, (Some SMEs can ill afford to provide their staff with training), Financial Times, Special Report - Professional Development, Monday, October 11, 4.

Moules, J. (2004b): Small business - Finding the time and money, Financial Times, Special Report - Professional Development, Monday, October 11, 4.

National Statistical Office (2002) in: Tot, E./Makó, C./Tamási, P. (2004): Occupational Profiling Orientation Stage - National Report for the Initial Exploration (Hungary) STILE (Statistics, Indicators, Labour Market, eEconomy) Project, Budapest: Institute of Sociology - Hungarian Academy of Sciences. 
Neumann, L. (2002): EIRO Comparative Study on Collective Bargaining Coverage and Extension Procedures - Case of Hungary, Budapest: Institute of Labour - Ministry of Employment Policy and Labour, 6.

Polányi, K. (1966): The Tacit Dimension, London: Routledge - Kegan Paul

Plimmer, G. (2004): Emphasis should be on more skill investment, (With technology evolving constantly, companies are being urged to be more aware of training needs and should invest more), Financial Times, October, 11.

Román, Z. (2002): Small and Medium-Sized Enterprises in the Hungarian Economy (State of Affairs and International Comparison), Budapest: Central Statistical Office.

Report on the Candidate Countries' Measures to Promote Entrepreneurship and Competitiveness, Brussels: Commission of the European Communities, Commission Staff Working Paper, CEC (2001).

Schwartz, K./Illéssy, M. (2004): The Tours Ltd. Company case study - (SMALL Project) Budapest: Institute of Sociology - Hungarian Academy of Sciences

Simonyi, Á/Andráska, Z./Bujdosó, J. (2004): The Hungarment Ltd. - Company case study Clothing industry (SMALL Project) Budapest: Institute of Sociology - Hungarian Academy of Sciences.

SMEs in Europe, Competitiveness, Innovation and the Knowledge-Driven Society, (2002) (Data 1996 - 2001) Brussels: Eurostat - EU Commission - Theme 4, Industry, trade and services.

Szígyártó, G./Janák, K./Farkas, G./Szunyogh, Z./Lázár, G. (2003): A gazdasági szervezetek saját munkavállalói számára biztosított kézések 1999. évben, (Training Offered Their Employees by Business Organizations), Budapest: Foglalkoztatáspolitikai és Munkaügyi Minisztérium (Ministry of Employment and Labour) - Központi Statisztikai Hivatal (Central Statistical Office).

Warhurst, C./Grugulis, I./Keep, E. (eds.) (2004): The Skills that Matter, London: Palgrave MacMillan.

Warhurst, C. (2004): Skills and Qualification at Work: Confusion and Conflation of Labour Market and Labour Process, Glasgow: Scottish Centre for Employment Research University of Strathclyde, (draft).

Working Conditions in the Accessing and Candidate Countries (2003): Dublin: European Foundation for the Improvement of Living and Working Conditions, www.eurofound.eu.int.

Ylinenpaa, H. (1997): Managing Competence Development and Acquisition in Small Manufacturing Firms, Lulea: Department of Business Administration and Social Sciences - University of Technology, in: Competence Development in SMEs (2003): Observatory of European SMEs, No. 1, 13.

2001. évi LI. Törvény a szakképzési hozzájárulásról és a képzési rendszer fejlesztésének támogatásáról (Law of 2001 LI. On the vocational training contribution and on the support of further development of the vocational training), Budapest: $1999-2001$ Magyar Hivatalos Közlönykiadó Kft. CD Jogász (® 2.20 - Hatályos Jogszabályok Hivatalos Gyüjteménye.

2001. évi CI. Törvény a felnőttképzésről, Budapest: 1992-2001. Magyar Hivatalos Közlönykiadó Kft., CD Jogász @ 2.20 Hatályos Jogszabályok Hivatalos Gyüjte. 


\section{Appendix}

Table 1. Defining SMEs - Commission Recommendation 95/280/EC and its Proposed Adaptation

\begin{tabular}{|l|c|c|c|c|c|}
\hline \multirow{2}{*}{$\begin{array}{l}\text { Size category } \\
\text { of firms }\end{array}$} & $\begin{array}{c}\text { No. of occupied } \\
\text { person less than } \\
\text { (unchanged from } \\
\text { the 1996 } \\
\text { Recommendation } \\
\text { ) }\end{array}$ & \multicolumn{2}{|c|}{$\begin{array}{c}\text { Recommendation } \\
\text { 96/280/EC (not } \\
\text { exceeding) }\end{array}$} & \multicolumn{2}{|c|}{$\begin{array}{c}\text { Updated proposal } \\
\text { (not exceeding) }\end{array}$} \\
\cline { 3 - 6 } & $\begin{array}{c}\text { Balance } \\
\text { sheet } \\
\text { (EUR) }\end{array}$ & $\begin{array}{c}\text { Turnover } \\
\text { (EUR) }\end{array}$ & $\begin{array}{c}\text { Balance } \\
\text { sheet } \\
\text { (EUR) }\end{array}$ & $\begin{array}{c}\text { Turnover } \\
\text { (EUR) }\end{array}$ \\
\hline $\begin{array}{l}\text { Micro } \\
\text { enterprise }\end{array}$ & 10 & - & - & 2 million & 2 million \\
\hline $\begin{array}{l}\text { Small } \\
\text { enterprise }\end{array}$ & 50 & 5 million & 7 million & 10 million & 10 million \\
\hline $\begin{array}{l}\text { Medium } \\
\text { sized } \\
\text { enterprise }\end{array}$ & 250 & 27 million & 40 million & 43 million & 50 million \\
\hline
\end{tabular}

Source: http://www.europa.eu.int/comm/enterprise/consultation/sme_definition/index.htm

Table 2. Relation Between the Level of Education and the Size Category of Firm

\begin{tabular}{|c|c|c|c|c|c|c|c|}
\hline \multirow[t]{2}{*}{$\begin{array}{l}\text { Highest qualification of } \\
\text { education }\end{array}$} & \multicolumn{6}{|c|}{$\begin{array}{l}\text { Share of employees by size category of firms } \\
(\%)\end{array}$} & \multirow[t]{2}{*}{ Total } \\
\hline & $0-4$ & $5-9$ & $10-49$ & $50-249$ & $0-249$ & $>250$ & \\
\hline Primary school & 14.6 & 13.5 & 17.9 & 20.6 & 16.7 & 19.0 & 17.3 \\
\hline \multicolumn{8}{|l|}{ Secondary school } \\
\hline $\begin{array}{l}\text { Providing no access to higher } \\
\text { education. }\end{array}$ & 39.0 & 38.8 & 38.7 & 41.8 & 39.4 & 35.8 & 38.5 \\
\hline $\begin{array}{l}\text { Providing access to higher } \\
\text { education }\end{array}$ & 34.7 & 35.6 & 31.9 & 26.2 & 32.3 & 32.7 & 32.4 \\
\hline College, university & 11.7 & 12.0 & 11.5 & 11.4 & 11.6 & 12.6 & 11.9 \\
\hline Total & 100.0 & 100.0 & 100.0 & 100.0 & 100.0 & 100.0 & 100.0 \\
\hline \multicolumn{8}{|l|}{ Men } \\
\hline Primary school & 13.6 & 14.1 & 16.9 & 15.3 & 15.2 & 15.8 & 15.3 \\
\hline \multicolumn{8}{|l|}{ Secondary school } \\
\hline Providing no G. C. E. & 45.9 & 46.5 & 46.9 & 50.4 & 47.1 & 43.1 & 46.2 \\
\hline Providing G. C. E. & 28.1 & 27.9 & 24.8 & 22.2 & 25.8 & 27.7 & 26.3 \\
\hline College, university & 12.4 & 11.5 & 11.4 & 12.1 & 11.8 & 13.3 & 12.2 \\
\hline Total & 100.0 & 100.0 & 100.0 & 100.0 & 100.0 & 100.0 & 100.0 \\
\hline \multicolumn{8}{|l|}{ Women } \\
\hline Primary school & 16.2 & 12.7 & 19.4 & 28.9 & 19.1 & 23.9 & 20.2 \\
\hline \multicolumn{8}{|l|}{ Secondary school } \\
\hline Providing no G. C. E. & 28.6 & 28.0 & 25.6 & 28.5 & 27.4 & 24.1 & 26.6 \\
\hline Providing G. C. E. & 44.4 & 46.5 & 43.2 & 32.4 & 42.2 & 40.7 & 41.8 \\
\hline College, university & 10.8 & 12.9 & 11.7 & 10.3 & 11.3 & 11.3 & 11.3 \\
\hline Total & 100.0 & 100.0 & 100.0 & 100.0 & 100.0 & 100.0 & 100.0 \\
\hline
\end{tabular}

Source: KSH, Labour Force Survey, 2002 (Lakatos/Lindnerne Eperjesi 2004:9) 
Table 3. Main Reasons for not Carrying Out Formal Training Activities in Denmark 2001, by Enterprise Size

\begin{tabular}{|c|c|c|c|c|c|}
\hline \multirow{2}{*}{$\begin{array}{l}\text { Barriers of } \\
\text { training }\end{array}$} & \multicolumn{5}{|c|}{ Size category of firms (no of persons employed) } \\
\hline & $1-9$ & $10-49$ & $50-199$ & $200+$ & Average \\
\hline $\begin{array}{l}\text { Insufficient } \\
\text { budget }\end{array}$ & $25 \%$ & $25 \%$ & $24 \%$ & $43 \%$ & $30 \%$ \\
\hline $\begin{array}{l}\text { No relevant } \\
\text { courses on } \\
\text { the market }\end{array}$ & $17 \%$ & $17 \%$ & $17 \%$ & $5 \%$ & $13 \%$ \\
\hline $\begin{array}{l}\text { No relevant } \\
\text { courses } \\
\text { nearby }\end{array}$ & $4 \%$ & $10 \%$ & $10 \%$ & $3 \%$ & $7 \%$ \\
\hline $\begin{array}{l}\text { Cancelled } \\
\text { courses }\end{array}$ & $4 \%$ & $4 \%$ & $12 \%$ & $8 \%$ & $8 \%$ \\
\hline $\begin{array}{l}\text { Lack of } \\
\text { knowledge of } \\
\text { the choice of } \\
\text { courses }\end{array}$ & $12 \%$ & $4 \%$ & $8 \%$ & $5 \%$ & $7 \%$ \\
\hline $\begin{array}{l}\text { Lack of } \\
\text { motivation } \\
\text { with the } \\
\text { employees }\end{array}$ & $8 \%$ & $15 \%$ & $5 \%$ & $7 \%$ & $8 \%$ \\
\hline $\begin{array}{l}\text { Lack of } \\
\text { motivation } \\
\text { with the } \\
\text { management }\end{array}$ & $12 \%$ & $13 \%$ & $15 \%$ & $11 \%$ & $13 \%$ \\
\hline Lack of time & $54 \%$ & $46 \%$ & $63 \%$ & $52 \%$ & $54 \%$ \\
\hline $\begin{array}{l}\text { Lack of } \\
\text { planning }\end{array}$ & $12 \%$ & $10 \%$ & $27 \%$ & $16 \%$ & $18 \%$ \\
\hline $\begin{array}{l}\text { Lack of } \\
\text { guidance }\end{array}$ & $4 \%$ & $6 \%$ & $5 \%$ & 0 & $4 \%$ \\
\hline Others & $8 \%$ & $15 \%$ & $14 \%$ & $13 \%$ & $13 \%$ \\
\hline Don`t know & $8 \%$ & $2 \%$ & $2 \%$ & $0 \%$ & $2 \%$ \\
\hline
\end{tabular}

Source: Competence Development in SMEs (2003)

Table 4. Share of Firms Introducing Product and Process Innovations: Hungary versus $E U-15$

\begin{tabular}{|l|c|c|}
\hline Size of firms & Average of the EU-15 & Hungary \\
\hline Small firms (<49 employees) & $44 \%$ & $19 \%$ \\
\hline $\begin{array}{l}\text { Medium-size firms } \\
(50-249 \text { employees })\end{array}$ & $58 \%$ & $38 \%$ \\
\hline $\begin{array}{l}\text { Large firms }(>250 \\
\text { employees })\end{array}$ & $79 \%$ & $64 \%$ \\
\hline
\end{tabular}

Source: Román, Z. (2002) 
Table 5. Case Studies Used in the Training Issue Analysis

\begin{tabular}{|l|c|c|}
\hline Sector & Firm & Author(s) \\
\hline Clothing industry & Hungarment Ltd. & $\begin{array}{c}\text { Simonyi, Ágnes -Andráska, } \\
\text { Zsófia - Bujdosó, Judit }\end{array}$ \\
\hline Tourism & Tours Ltd. & $\begin{array}{c}\text { Schwartz, Kitti - Illéssy, } \\
\text { Miklós }\end{array}$ \\
\hline ICT (interactive media) & Kowalsky Co. & Csizmadia, Péter \\
\hline
\end{tabular}

Table 6. Persons Interviewed by Sectors in the Company Case Studies

\begin{tabular}{|c|c|}
\hline Sector & Persons Interviewed \\
\hline $\begin{array}{l}\text { I. Clothing („Hungarment Ltd.”, established } \\
\text { in 1998, number of employees: } 6 \text { persons) }\end{array}$ & $\begin{array}{l}\text { - Deputy Secretary of „Hungarian Society of } \\
\text { Textile Technology and Science” } \\
\text { - Head of „Foundation for Supporting } \\
\text { Entrepreneurship” } \\
\text { Leader of „Textile and Clothes Industry } \\
\text { Dept. of the Entrepreneurs' Association” } \\
\text { Vice President of Trade Union of Worker of } \\
\text { Garment Trade } \\
\text { Owner of a sewing company and servant in } \\
\text { „Budapest Chamber of Commerce” } \\
\text { Managing director of „Hungarment Ltd.” } \\
\text { Sewer (Hungarment Ltd.) }\end{array}$ \\
\hline $\begin{array}{l}\text { II. Tourism (,Tours Ltd., established in } \\
\text { 1995, number of employees } 6 \text { persons) }\end{array}$ & $\begin{array}{l}\text { Director of „Hungarian Tourism Office” and } \\
\text { „National Committee on Tourism” } \\
\text { Owner of a travel agency and Vice President } \\
\text { of „Budapest Chamber of Commerce” } \\
\text { Vice President of „Hungarian Association of } \\
\text { Travel Agencies” } \\
\text { Head of Department of „Holiday Travel } \\
\text { Agency” } \\
\text { Head of Department of „Relax Travel } \\
\text { Agency” } \\
\text { President of „Hungarian Tour Operators’ } \\
\text { Association” and Managing Director of } \\
\text { „Tours Ltd.” } \\
\text { Owner (Tours Ltd.) } \\
\text { Tour Operator (Tours Ltd.) }\end{array}$ \\
\hline $\begin{array}{l}\text { III. ICT (interactive media) („Kowalsky Co., } \\
\text { established in 1996, number of employees: } \\
62 \text { persons) }\end{array}$ & $\begin{array}{l}\text { Vice president of „Hungarian Association of } \\
\text { IT Companies” } \\
\text { Head of e-Economy Department of the } \\
\text { „Ministry of Informatics and } \\
\text { Communications” } \\
\text { Head of New Media Division of „Kowalsky } \\
\text { Co.” } \\
\text { Senior developer (Kowalsky Co.) } \\
\text { Digital media manager (Kowalsky Co.) } \\
\text { Digital media manager (Kowalsky Co.) }\end{array}$ \\
\hline
\end{tabular}

